\title{
Diamondiferous Minette Dykes from the Parker Lake Area, N.W.T., Canada
}

Kaminsky, F.V. ${ }^{1}$, Sablukov, S.M. ${ }^{2}$, Sablukova, L.I. ${ }^{2}$, Shpanov, V.E. ${ }^{2}$, and Zhuravlev, D.Z. ${ }^{3}$

1. KM Diamond Exploration, 815 Evelyn Drive, West Vancouver, B.C. V7T 1J1, Canada, Tel. \& Fax (1-604) $925-$ 8755, E-mail: kaminsky@fox.nstn.ca

2. Institute of Diamonds, Russian Academy of Natural Sciences, 155-5/10 Litovskii Blvd., Moscow 117593, Russia

3. Institute of Ore Deposits, Russian Academy of Sciences, Staromonetnii 35, Moscow 109017, Russia

Geology. As a result of work of Canadian and Russian geologists in 1994-1996, four diamondiferous minette dykes were discovered in the Parker Lake area, N.W.T., Canada. The area is located west of Hudson Bay between Rankin Inlet and Baker Lake within the Churchill Province, which is considered to be a nucleus for the Laurentian supercontinent. The area belongs to the Hearne Eocraton with mainly juvenile Late Archean (2.8-2.6 Ga) crust with rare relics of older gneiss $(3.1$ to $2.9 \mathrm{Ga}$ ). This portion of the Churchill Province between the Proterozoic orogens is known as the Keewatin Hinterland. It is an area of wide development of potassic and ultrapotassic volcanism including Proterozoic Christopher Island Formation (CIF) lamprophyric dykes.

Three diamondiferous minette dykes, the Thirsty Lake Dyke, the South Dyke and the North Dyke form a large, single zone (the Akuilak system), over $15 \mathrm{~km}$ in length. The dykes show rather constant thicknesses of 1-2 m and, locally, up to 4-8 m. They are, in general, oriented in a N-S direction and dip steeply to the east. Each of the dykes is a system of separate rock bodies that are arranged en echelon and wedge in and out along its general strike. The dykes are accompanied by tongues, which may be removed by as far as $100 \mathrm{~m}$ from the main body. This fact suggests that extensive tectonic displacement took place during the dyke formation.

The $V$-Day Dyke is the smallest of the dykes known at present within this area. Its total length is about $300 \mathrm{~m}$. It is possibly a part of another system of submeridionally orientated minette dykes.

Age. Because CIF lamprophyre dykes cross-cut the minette dykes, the minette dykes are interpreted to be older than the CIF lamprophyric dykes. Their $\mathrm{Rb}$-Sr age is $1867+/-30 \mathrm{Ma}$, what coincides with a $1832+/-50 \mathrm{Ma} \mathrm{U}-\mathrm{Pb}$ age reported earlier by McRae et al.

Petrography. The rocks of all four minette dykes are very similar in mineral composition and textural features. They have a holocrystalline, fine- to medium-grained, poikilitic texture. The essential minerals that compose the rock are microcline (which contains numerous inclusions of biotite, apatite and carbonate), apatite, carbonate and epidote. Accessory minerals in the dyke rocks are represented by sphene, zircon and ore minerals. The metamorphosed character of the rock is further evidenced by ocellar textural elements that occur in several segments of the dykes. Grain morphology observations suggest that apatite may be the only primary (relict) mineral of the minette. Dyke rocks contain xenoliths of various altered rock types. The xenoliths are large (up to $0.5 \mathrm{~m}$ ) and rounded, which suggests that active crusting, melting and, possibly explosive processes might have been involved in the dyke formation.

Geochemistry. Geochemically, rocks of the four dykes form a unique group, distinct from kimberlites, lamproites and high- $\mathrm{K}$ basaltic rocks. They are rather similar, though not identical, to intermediate minette. There might be some correlation with CIF lamprophyres (Figure 1). 
Geochemical similarity of the metasomatic inclusion and its enclosing minette suggests that the minette itself has also experienced metasomatic alteration. Dyke rocks exhibit low $\mathrm{SiO}_{2}$ content (40.31-45.55\%). $\mathrm{Al}$ and $\mathrm{Mg}$ contents of dyke rocks are similar to those of mafic rocks. Fe and $\mathrm{Ti}$ contents are low to intermediate. Concentrations of compatible elements typical for ultramafic rocks $(\mathrm{Ni}, \mathrm{Co}, \mathrm{Cr})$ are very low. Dyke rocks compositions are ultra-potassic $\left(\mathrm{K}_{2} \mathrm{O} / \mathrm{Na}_{2} \mathrm{O}=4\right.$ to 50$)$. Concentrations of incompatible elements in dyke rocks are very high, and their distribution is rather peculiar. Minette has very high concentrations of $\mathrm{Zr}$ (from 200 to $1400 \mathrm{ppm}$ ), Hf, P, Eu; and very low concentrations of $\mathrm{Ti}, \mathrm{Nb}$ (from 5 to $19 \mathrm{ppm}$ ) and $\mathrm{Ta}$ (from 0.5 to $2.8 \mathrm{ppm}$ ). $\mathrm{K}, \mathrm{Rb}, \mathrm{Sr}$ and $\mathrm{Ba}$ concentrations are rather high.

Nd and Sr isotope composition of minettes is the same as in CIF lamprophyres (Figure 2).

High-pressure minerals. Olivine, clinopyroxene, pyrope, picroilmenite and diamond have been found in the minettes.

Olivine occurs in small fragments. It is almost colourless with a slight yellowish tint. This olivine is classed as a highly magnesian variety (Fo 94), which is typical for kimberlites and lamproites.

Grains of emerald-green chrome diopside were found as fragments of oval grains. Grain faces are jointy, nontransparent and feature sugary spallation surfaces. By its composition, this mineral is classed as typical chrome-diopside, high in chromium $\left(2.81 \% \mathrm{Cr}_{2} \mathrm{O}_{3}\right)$ and highly-calcic $(47 \%$ $\mathrm{CaO})$. Its peculiar feature is a rather low alumina content $\left(0.33 \% \mathrm{Al}_{2} \mathrm{O}_{3}\right)$.

Pyrope grains are pale violet and orange angular grain fragments with preserved relics of primary magmatic surface. The surface is micropectinal-undulated. Compositionally, all pyrope grains found here are classed with lherzolitic paragenesis, with $\mathrm{Cr}_{2} \mathrm{O}_{3}$ contents varying between $1.48 \%$ and $6.12 \%$. All violet pyrope varieties show low $\mathrm{Ti}$ contents $\left(<0.13 \% \mathrm{TiO}_{2}\right)$, while the orange ones are rich in titanium $\left(0.39-1.04 \% \mathrm{TiO}_{2}\right)$. In terms of Dawson-Stephens' classification, they fall within the G9 (chromic pyrope) and G1 (titanic pyrope) groups correspondingly.

Picroilmenite. A few ilmenite grains were found in minette. They are classed by their compositional specificity as a highly magnesian picroilmenite variety $(>12 \% \mathrm{MgO})$, with moderate $\mathrm{Al}_{2} \mathrm{O}_{3}$ content and habitual $\mathrm{Cr}_{2} \mathrm{O}_{3}$ admixture $(0.77-1.14 \%)$ which are typical for kimberlites.

Diamonds were found in three minette samples. Grain size varies from 0.08 to $0.5 \mathrm{~mm}$, with a maximum at $0.25 \mathrm{~mm}$. Diamond grains occur as whole crystals and crystal fragments. Morphologically, the diamonds are rounded dodecahedroids, tetrahaxedroids, cubes and, more rarely, flat-faced octahedra and spinel twins. All the crystals are coloured. Predominantly, they are dirty-green and brown, but green and yellow crystals were also found. Carbon isotope composition of diamonds is variable $\left(d^{13} \mathrm{C}=-3.3\right.$ to $\left.-16.4 \%\right)$ with a mode at $9-10 \%$.

Conclusions. Four diamondiferous minette dikes (the North Dyke, Thirsty Lake Dyke, South Dyke and V-Day Dyke) are identical in geological structure and material composition. The dyke rocks are metamorphosed and have undergone metasomatism, but they have retained indications of their mantle origin. They represent a new type of diamondiferous rocks formed from a metasomatized lithosphere mantle. 


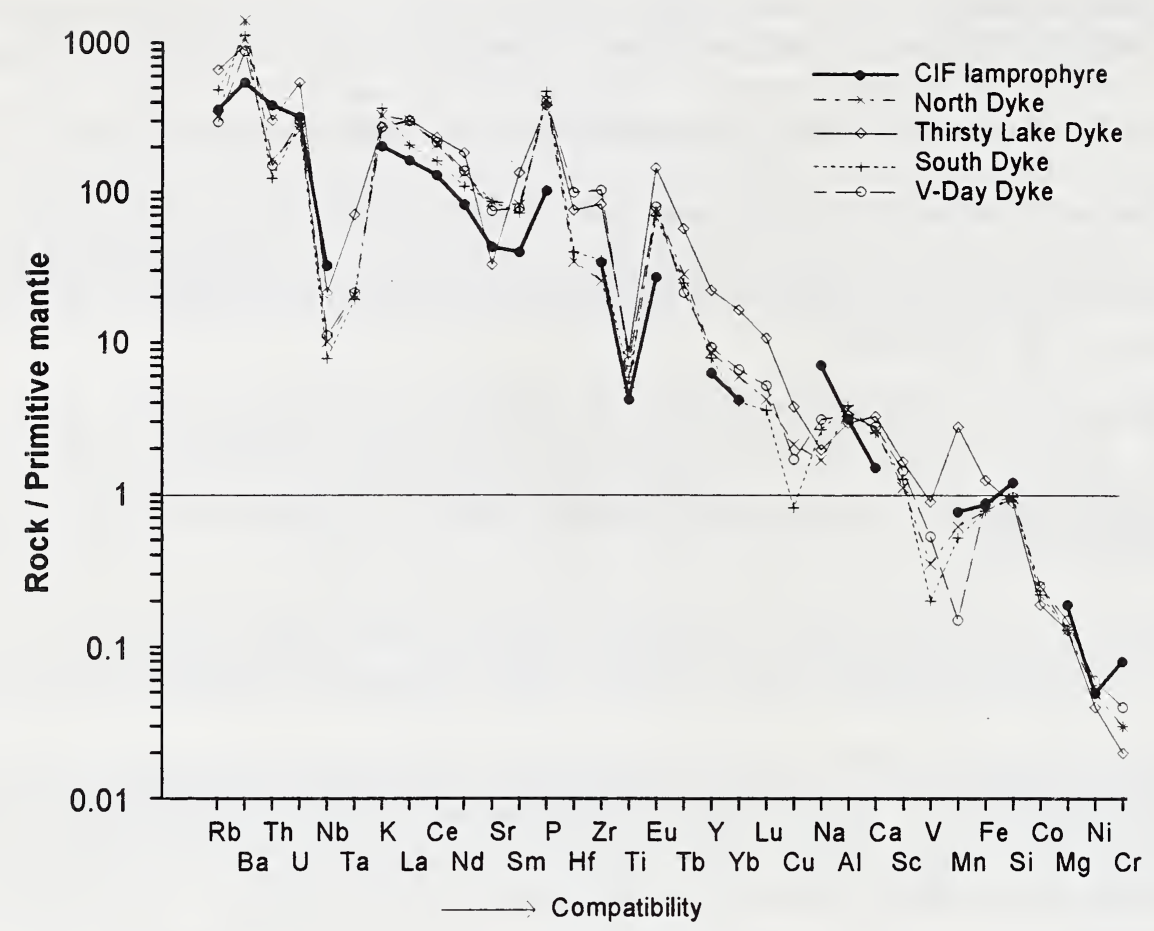

Figure 1. Normalized (after Jagoutz et al.,1979) abundance pattern diagrams for minette dykes

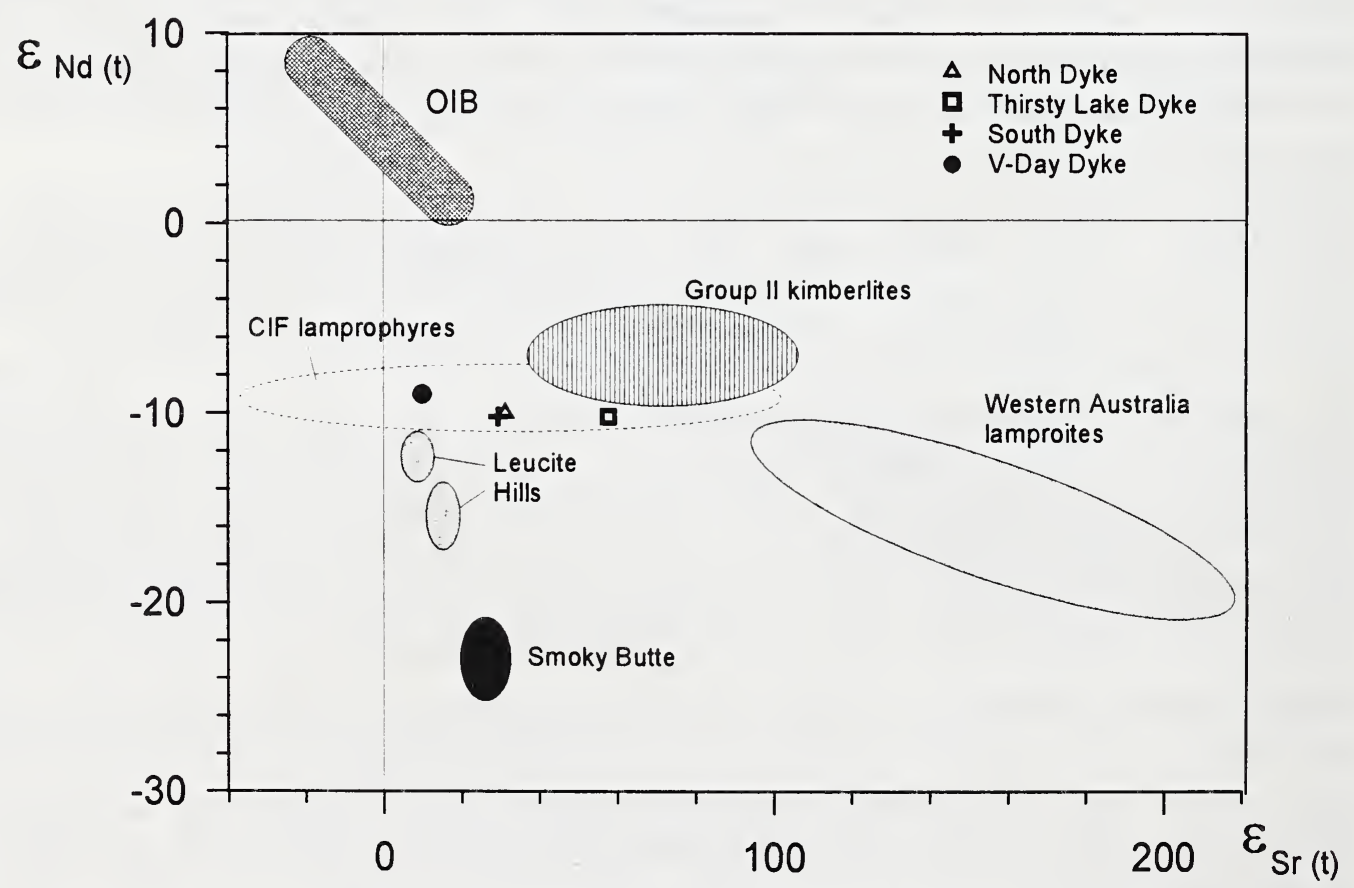

Figure 2. $\varepsilon_{\mathrm{Nd}}$ vs $\varepsilon_{\mathrm{Sr}}$ at $1.84 \mathrm{Ga}$ for the CIF lamprophyres (Peterson et al.,1994) and minettes. 